\title{
Specyfika komunikacji werbalnej i niewerbalnej dziecka z zespołem Aspergera w kontekście odgrywanej przez nie roli ucznia i kolegi
}

\begin{abstract}
Ewa Gacka, Specyfika komunikacji werbalnej i niewerbalnej dziecka z zespołem Aspergera w kontekście odgrywanej przez nie roli ucznia $i$ kolegi [Specificity of verbal and non-verbal communication of a child with Asparger syndrome in the context of their leading role of acting as a pupil and a colleague]. Interdyscyplinarne Konteksty Pedagogiki Specjalnej, nr 19, Poznań 2017. Pp. 153-166. Adam Mickiewicz University Press. ISSN 2300-391X

Communication is one of the most important elements of human existence, because man as a social being strives to communicate with others. Communication skills influence the degree of acceptance of the person by other members of the community and they help to achieve success in various aspects of life and social roles. The article focuses on the analysis of communication skills, both verbal and nonverbal, of a child with Asperger syndrome (AS). The purpose of this article is to show the specific way people communicate with Asparger syndrome child, which makes it difficult for him to find himself in the school community - being a good pupil and good colleague.
\end{abstract}

KEY WORDS: Asperger syndrome, verbal communication, nonverbal communication, social role 


\section{Rola społeczna - zakres znaczeniowy pojęcia}

W socjologii pojecie roli społecznej wiąże się z pozycją społeczną, statusem społecznym, który lokuje człowieka w zbiorowości. Rolę społeczną można zdefiniować jako „zespół praw i obowiązków związanych z daną pozycją [...] schemat zachowania związanego z pozycją"1. Pewne biologiczne czy psychiczne cechy człowieka mogą utrudniać lub uniemożliwiać odgrywanie ról społecznych. Tak dzieje się w przypadku osób z różnego rodzaju niepełnosprawnościami, zaburzeniami rozwojowymi, w tym z zespołem Aspergera (ZA).

Rola społeczna wyznacza sposób zachowania osoby zajmującej określoną pozycję społeczną, czyli precyzuje obowiązujące ją normy zachowania. Te normy dotyczą także komunikacji, „zachowania językowe wyznaczają i obrazują możliwości istnienia człowieka grupie społecznej”2. Rola kolegi szkolnego wymaga zachowań, w których liczy się współpraca, współdziałanie, punkt widzenia drugiej osoby, wspólne uzgodnienia, wzajemna pomoc, umiejętność kompromisu i empatii. Rola ucznia obliguje do respektowania regulaminu szkoły, obecności na zajęciach, punktualności, odrabiania pracy domowej, aktywności na lekcjach, skupienia, przestrzegania rytmu komunikacyjnego obowiązującego na lekcji, okazywania szacunku nauczycielom, umiejętności pracy w zespole.

Naruszenie norm związanych z określoną rolą społeczną wiąże się z sankcjami, mniej lub bardziej formalnymi. Kobietę niewywiązującą się z roli matki może spotkać kara formalna - odebranie jej praw rodzicielskich lub sankcja mniej formalna - krytyka i potępienie ze strony otoczenia. Dziecko niewywiązujące się z zadań ucznia naraża się na sankcje w postaci upomnienia, ustnej nagany ze strony nauczyciela, otrzymania negatywnej oceny czy też braku promocji do następnej klasy. Karą za naruszenie norm obowiązujących

${ }^{1}$ B. Szacka, Wprowadzenie do socjologii, Oficyna naukowa, Warszawa 2008, s. 149.

2S. Grabias, Postępowanie logopedyczne. Diagnoza, programowanie terapii, terapia, „Logopedia” 2008, t. 28, s. 13-37. 
"dobrego kolegę" może być wykluczenie ze społeczności klasowej, niezapraszanie na klasowe imprezy, niedopuszczanie do wspólnej zabawy, wyśmiewanie czy dokuczanie. Trzeba też pamiętać, że ocena zachowania osoby pełniącej daną funkcję zależy od tego, kto jej dokonuje. $W$ przypadku roli kolegi mogą istnieć rozbieżności pomiędzy poglądami rodziców i nauczycieli a samymi dziećmi, które dopuszczają w ramach koleżeńskiej współpracy „odpisywanie" pracy domowej czy "ściąganie” na klasówkach. Ponieważ odgrywanie ról społecznych wiąże się z byciem w zbiorowości (wśród innych osób) istotną kwestią jest sposób komunikowania się.

\section{Komunikacja werbalna i niewerbalna}

Komunikowanie się (porozumiewanie się) to wymiana informacji, żądań, próśb, poglądów, odczuć pomiędzy nadawcą i odbiorcą, a więc czynność o charakterze dwustronnym, interakcyjnym. W logopedii interakcję określa się jako „układ dwu przylegających do siebie procesów: procesu nadawania znaczeń zachowaniom ludzkim oraz procesu dostosowywania własnych zachowań do zachowań członków danej grupy społecznej"3. A więc porozumiewanie się rozumiane jako interakcja to wzajemne dostosowanie się stron w nim uczestniczących.

W komunikacji posługujemy się różnymi kodami: językowym, parajęzykowym i pozajęzykowym ${ }^{4}$. W porozumiewaniu językowym środkiem użytym do komunikowania się jest język. W komunikacji parajęzykowej stosuje się melodię, akcent, rytm, zaś komunikacja pozajęzykowa wykorzystuje mimikę, gest, ruch ciała, spojrzenie, proksemikę. Komunikacja werbalna to komunikacja słowna, którą Bożydar Kaczmarek traktuje jako jeden z elementów składowych komunikacji językowej - poza pisemną i sygnaliza-

${ }^{3}$ S. Grabias, Interakcja jezykowa $i$ jej uwarunkowania. Perspektywa lingwistyczna, [w:] Bariery i pomosty w komunikacji językowej Polaków, red. J. Bartmiński, U. Majer-Baranowska, Wydawnictwo UMCS, Lublin 2005, s. 19.

${ }_{4}^{4}$ B. Kaczmarek, Misterne gry w komunikacje, Wyd. UMCS, Lublin 2010. 
cyjną ${ }^{5}$. W komunikacji niewerbalnej wykorzystuje się środki parajęzykowe i pozajęzykowe. Zazwyczaj w procesie komunikacji stosujemy wszystkie kody jednocześnie, przekazujemy intencje za pomocą wypowiadanych słów, odpowiedniego akcentu, intonacji, ale także przy pomocy mimiki czy gestów.

Analizując proces komunikowania się, trzeba brać pod uwagę: osoby uczestniczące w wymianie informacji tzw. komunikantów, cele, którym służy komunikacja, sposób i kanał przekazu informacji, sam komunikat, czyli tekst, kod przekazu, a także sytuacje (okoliczności) w jakich dochodzi do komunikacji ${ }^{6}$. Przyczynami trudności komunikacyjnych mogą być wszystkie z wymienionych elementów. Aby komunikacja była efektywna, obie strony (nadawca oraz odbiorca) powinny znać te same kody przekazu (językowy, parajęzykowy i pozajęzykowy) i właściwie interpretować komunikaty. Ważny jest także kontekst sytuacyjny, w którym dochodzi do wymiany informacji, jego nieuwzględnienie, a co za tym idzie, nieumiejętność dostosowania komunikatu do okoliczności może stanowić przyczynę zakłóceń w porozumiewaniu się. Czynnikami utrudniającymi komunikację są też pewne ograniczenia biopsychiczne zarówno nadawcy, jak i odbiorcy (komunikantów), jak to ma miejsce w przypadku osób np. upośledzonych umysłowo czy autystycznych. Porozumiewanie wymaga współpracy (kooperacji). Filozof języka Paul Grice wśród zasad językowej komunikacji wymienia maksymy: ilości (mówimy tyle, ile potrzeba), jakości (mówimy to, co wiemy, że jest prawdą, unikamy nieprawdy), odniesienia do tematyki (mówimy to, co związane jest z tematem), sposobu (mówimy zrozumiale) ${ }^{7}$.

Większość ludzi w procesie komunikowania się wykorzystuje mowę. Zgodnie z ujęciem Stanisława Grabiasa jest ona „układem

${ }^{5}$ Ibidem.

${ }^{6}$ S. Gajda, Jak się porozumiewamy?, [w:] Logopedia. Pytania i odpowiedzi. Podręcznik akademicki. Interdyscyplinarne podstawy logopedii. Tom I, red. T. Gałkowski, G. Jastrzębowska, Wydawnictwo Uniwersytetu Opolskiego, Opole 2003, s. 19-26.

${ }^{7}$ H.P. Grice, Logic and conversation, [w:] Syntax and semantics, red. P. Cole, J.L. Morgan, V/3, Academic Press, New York 1975, s. 41-58; H.P. Grice, Logika i konwersacja, „Przegląd Humanistyczny” 1977, nr 6, s. 85-99. 
czynności, jakie przy udziale języka wykonuje człowiek, poznając świat i przekazując wiedzę o sobie i świecie innym uczestnikom życia społecznego"8. Z przedstawionej definicji wynika, że język odgrywa nie tylko rolę komunikacyjną, ale i poznawczą. Język pozwala człowiekowi interpretować świat i jednocześnie przekazywać to, co wiemy o świecie innym ludziom, wpływać na nich. Obydwie funkcje języka (poznawcza i komunikacyjna) wzajemnie się uzupełniają. Podkreśla się, że „nasze powodzenie w różnych sytuacjach w dużej mierze zależy od tego, na ile umiemy wykorzystać możliwości zawarte w mowie" ${ }^{\prime \prime}$, a więc możliwości jakie daje język.

\section{Zespół Aspergera - kryteria diagnostyczne}

Jednym z kryteriów diagnostycznych zespołu Aspergera jest charakterystyczny sposób komunikowania się, specyficzna mowa. Zaburzenie nazywane dzisiaj zespołem Aspergera zostało po raz pierwszy opisane przez wiedeńskiego psychiatrę i pediatrę Hansa Aspergera, który w opublikowanej w 1944 r. pracy przedstawił przypadki pacjentów ze swoistymi cechami w zachowaniu i komunikowaniu się ${ }^{10}$. Termin „,zespól Aspergera” został upowszechniony i wprowadzony do literatury przedmiotu w 1981 r. przez Lornę Wing.

W Międzynarodowej Statystycznej Klasyfikacji Chorób i Problemów Zdrowotnych ICD-10 zespół Aspergera znajduje się wśród całościowych zaburzeń rozwoju i jest oznaczony symbolem (84.5)11.

8 S. Grabias, O ostrość refleksji naukowej. Przedmiot logopedii i procedury logopedycznego postepowania, [w:] Logopedia. Wybrane aspekty historii, teorii i praktyki, red. S. Milewski, K. Kaczorowska-Bray, Harmonia Universalis, Gdańsk 2012, s. 61.

${ }^{9}$ S. Gajda, Wprowadzenie, [w:] Logopedia. Pytania i odpowiedzi. Podręcznik akademicki. Interdyscyplinarne podstawy logopedii.. Tom I, red. T. Gałkowski, G. Jastrzębowska, Wyd. UO, Opole 2003, s. 12.

${ }^{10}$ D. Graaisma, Rozstrojone umysty. Dzieje chorób i historie chorób, PIW, Warszawa 2009.

${ }^{11}$ Klasyfikacja zaburzeń psychicznych i zaburzeń zachowania w ICD-10. Badawcze kryteria diagnostyczne, red. S. Pużyński, J. Wciórka, Uniwersyteckie Wydawnictwo Medyczne „Vesalius”, Instytut Psychiatrii i Neurologii, Warszawa 2007. 
Amerykańskie Towarzystwo Psychiatryczne włączyło go do oficjalnej klasyfikacji w roku 1994. W najnowszej, V rewizji DSM został zaklasyfikowany do zaburzeń ze spektrum autyzmu, bez podania osobnych kryteriów diagnostycznych ${ }^{12}$.

Wokół ZA narosło wiele kontrowersji. Dyskusje dotyczą tego, czy jest odrębną jednostką kliniczną, czy też pewną odmianą autyzmu, co znajduje odbicie w jego usytuowaniu w różnych klasyfikacjach (patrz: ICD-10, DSM -IV, DSM-V). Nie ma także zgodności co do oceny początkowych etapów rozwoju mowy u osób z tym rozpoznaniem. W publikacjach naukowych i kryteriach diagnostycznych spotkać można dwa stanowiska. W jednych podkreśla się brak opóźnień w rozwoju mowy u dzieci z $Z^{13}$, w innych dopuszcza się możliwość ich istnienia14. Stwierdzenie o braku opóźnień w rozwoju mowy obecne $\mathrm{w}$ medycznych kryteriach diagnostycznych dla ZA (DSM-IV, ICD-10) amerykański wykładowca psychia-

12 J Morrison, DSM-V® bez tajemnic. Praktyczny przewodnik dla klinicystów, Wydawnictwo UJ, Kraków 2016.

${ }^{13}$ Klasyfikacja zaburzeń psychicznych...; Diagnostic and statistical manual of mental disorders, 4 th Ed, rev. (DSM-IV), American PsychiatricAssotiation, Washington 1994; A. Maciarz, M. Biedasiewicz, Dziecko autystyczne z zespołem Aspergera. Studium przypadku, Oficyna Wydawnicza „Impuls”, Kraków 2000; J. Urbaniak, Mali profesorowie czy inteligentni autyści. Wczesna diagnoza dziecka z zespołem Aspergera, [w:] Wczesna interwencja i wspomaganie rozwoju małego dziecka, red. B. Cytowska, B. Winczura, Oficyna Wydawnicza „Impuls”, Kraków 2006, s. 399-428; B. Winczura, Autyzm, autyzm atypowy a schizofrenia wczesnodzieciecca, [w:] Dzieci z zaburzeniami taczonymiTrudne ścieżki rozwoju, Oficyna Wydawnicza „Impuls”, Warszawa 2012, s. 63-118; J.J. Błeszyński, Autyzm a niepetnosprawność intelektualna i opóźnienie w rozwoju. Skala oceny zachowań autystycznych, Harmonia Universlis, Gdańsk 2016.

14 G. Gilberg, C. Gillberg,, Asperger syndrome - Some epidemiological considerations: A reaserch note, "Journal of Child Psychology and Psychiatry", vol. 30, s. 631-63; T. Attwood, Zespót Aspergera, Zysk i S-ka, Poznań 2006; M. Korendo, Językowa interpretacja świata w wypowiedziach osób z zespołem Aspergera, Omega Stage Systems, Kraków 2013; J. Cieszyńska-Rożek, Metoda Krakowska wobec zaburzeń rozwoju dzieci. $Z$ perspektywy fenomenologii, neurobiologii $i$ jezykoznawstwa, Omega Stage Systems, Kraków 2013; S. Błaszczyk-Kowalska, E. Gacka, Rozwój komunikacji językowej u dzieci z zespołem Aspergera, „Problemy opiekuńczo-Wychowawcze” 2015, nr 10, s. 3-13. 
trii James Morrison, komentuje w następujący sposób: „to paradoks, że z powodu opóźnienia rozwoju języka Temple Grandin nie spełniłaby kryteriów tej diagnozy [zespołu Aspergera - przypis E.G.] według DSM-IV, choć pozostaje modelową osobą w przypadku tego zaburzenia"15.

Autorce prezentowanego artykułu najbliższe jest stanowisko wyróżniające dwa modele rozwoju mowy u osób z ZA: z opóźnieniem w rozwoju mowy i bez opóźnień w kształtowaniu się mowy. U części dzieci z tym rozpoznaniem (co potwierdza także wieloletnia praktyka logopedyczna piszącej te słowa) mowa rozwija się z przesunięciem w czasie. Później niż większość typowo rozwijających się rówieśników zaczynają wypowiadać pierwsze słowa i pierwsze zdania, a w pojawiających się z opóźnieniem wypowiedziach można stwierdzić charakterystyczne nieprawidłowości. W drugim modelu mowa rozwija się bez opóźnień tzn. dzieci zaczynają wypowiadać pierwsze słowa i pierwsze zdania o czasie, ale $\mathrm{w}$ ich sposobie komunikacji (werbalnej i niewerbalnej) obecne są swoiste dla ZA cechy.

Wśród cech diagnostycznych zespołu Aspergera wymienia sięie:

- niedojrzały i jednostronny typ interakcji społecznych,

- upośledzenie empatii,

- nieadekwatne wyrażanie i rozpoznawanie emocji innych osób,

- pedantyczny, encyklopedyczny język,

- schematyzm wypowiedzi,

- dosłowność w odbiorze języka,

- ubogą komunikację niewerbalną,

- impulsywność,

- zaburzenia intonacji i akcentu,

15 J. Morrison, op. cit., s. 47.

${ }^{16}$ ICD-10; DSM-IV; T. Attwood, op. cit.; A. Bryńska, Deficyty językowe w zespole Aspergera jako możliwy wyraz dysfunkcji prawopótkulowej. „Psychiatria i psychologia kliniczna" 2010, 10(4), s. 247-253; M. Korendo, op. cit.; J. Panasiuk, M.M. Kaczyńska-Haładyj, Postępowanie logopedyczne w przypadku osób dorostych z zespołem Aspergera, [w:] Logopedia. Standardy postępowania logopedycznego. Podręcznik akademicki, red. S. Grabias, J. Panasiuk, T. Woźniak, Wydawnictwo UMCS, Lublin 2015, s. 517-549. 
- silne skupianie się na własnych zainteresowaniach, uporczywe trzymanie się pewnych tematów,

- trudności z zachowaniem rytmu komunikacyjnego,

- niezgrabność ruchowa, „dziwaczną postawę”.

\section{Charakterystyka sposobu komunikacji dzieci z zespołem Aspergera}

Analiza kryteriów diagnostycznych pozwala na wyodrębnienie tych związanych z komunikacją zarówno werbalną (słowną), jak i niewerbalną. U polskojęzycznych dzieci z zespołem Aspergera występują trudności ze stosowaniem form fleksyjnych, a co za tym idzie, trudności z budowaniem tekstu. Brak tego typu problemów $\mathrm{u}$ anglojęzycznych dzieci można tłumaczyć specyfiką języka angielskiego, który w przeciwieństwie do polskiego nie jest językiem fleksyjnym. Dzieci z zespołem Aspergera mają trudności w rozumieniu i wyrażaniu stosunków przestrzennych, czasowych, przyczynowoskutkowych. Dla przykładu, w trakcie sesji terapeutycznej dziecko z zespołem Aspergera na pytanie badającej „Dlaczego należy myć ręce przed jedzeniem”, odpowiada: "Aby je wytrzeć ręcznikiem”, a na pytanie "Dlaczego chłopiec ma siedzieć cicho", udziela odpowiedzi: „Żeby nic nie mówić"17. Narracja osób z ZA jest niespójna, wielowątkowa, chaotyczna, co utrudnia relacje z kolegami z klasy, ale może też utrudnić komunikację z nauczycielem, gdyż „przeskakiwanie" z tematu na temat zakłóca odbiór wypowiedzi przez otoczenie.

Dzieci z ZA nie rozumieją przenośni, metafor, żartów, w związ$\mathrm{ku} \mathrm{z}$ czym problem sprawia im interpretacja wiersza, a także zrozumienie morału wynikającego z przeczytanej bajki. Dosłowność i schematyzm w odbiorze języka powodują, że nie zdają sobie one sprawy z wieloznaczności wyrazów tzw. homonimów. I tak pacjent poproszony o wskazanie różnicy pomiędzy obrazkami, zdziwiony

${ }^{17}$ Przykłady pochodzą z praktyki logopedycznej autorki artykułu. 
patrzy na logopedę i mówi: „Ależ Pani Ewo, tu nie ma różnicy, różnica to... [chwilę zastanawia się - przypis E.G.] odejmowanie, a gdzie tu jest odejmowanie"18.

Nierozumienie żartów, przenośni, powiedzonek staje się przyczyną konfliktów z rówieśnikami. Kontakty koleżeńskie zaburza także szablonowość wypowiedzi, np. używanie tej samej formy powitania bez względu do kogo jest kierowana czy zwracanie się do kolegów pełnym imieniem i nazwiskiem np. "Janie Nowaku”. Pedantyczny, formalny i "dorosły” język dziecka z zespołem Aspergera powoduje, że jest ono traktowane jako przemądrzałe lub „dziwaczne”.

Wąski zakres zainteresowań wiąże się z uporczywym powracaniem do pewnych tematów (tych, które są pasjonujące dla dziecka). Marta Korendo podkreśla nierównomierny rozwój słownictwa $\mathrm{u}$ dzieci z ZA związany ze specyficznymi zainteresowaniami i istnienie tzw. kominów językowych, czyli nadmiernie rozbudowanego słownictwa $\mathrm{z}$ danej kategorii semantycznej przy jednoczesnych trudnościach $\mathrm{w}$ obszarach, $\mathrm{z}$ którymi większość typowo rozwijających się dzieci nie ma trudności np. z nazwami kolorów czy posiłków ${ }^{19}$.

Proces komunikacji dzieci z zespołem Aspergera mogą zaburzać echolalie: jawne i ukryte. Echolalie ukryte, to powtarzanie usłyszanych fragmentów wypowiedzi (np. pochodzących z reklam), co prawda adekwatnie do istniejących okoliczności, ale bez rozumienia znaczenia słów, jedynie przy uchwyceniu kontekstu sytuacji ${ }^{20}$. Drugi rodzaj ukrytych echolalii to wymuszanie na rodzicach lub innych osobach wypowiadania użytego przez nich wcześniej słowa lub zwrotu, zawsze w danych okolicznościach. Jeżeli dziecku spodobał się jakiś zwrot osoby dorosłej, domaga się, aby powtarzać je każdorazowo $\mathrm{w}$ podobnej sytuacji $\mathrm{np}$. podczas zakupów czy gotowania obiadu. Uczeń z zespołem Aspergera może zatem oczekiwać od

\footnotetext{
18 Przykład pochodzi z praktyki logopedycznej autorki artykułu.

${ }^{19}$ M. Korendo, op. cit.

${ }^{20}$ J. Cieszyńska-Rożek, op. cit.
} 
nauczyciela, że ten zawsze np. podczas sprawdzania listy obecności czy prosząc o wykonanie pewnego ćwiczenia, będzie zwracał się do dziecka w określony sposób. Echolalie jawne to powtarzanie zasłyszanej wypowiedzi niezależnie od kontekstu sytuacji.

Problemem dla dzieci z ZA jest przestrzeganie zasady naprzemienności w porozumiewaniu się (rytmu komunikacyjnego). Zachowania niezgodnie $z$ regułą naprzemienności, a więc nieumiejętność prowadzenia dialogu lub dyskusji często kończy się wyłączeniem z grupy rówieśniczej, upomnieniem ze strony nauczyciela czy uwagami innych dorosłych o braku należytego „wychowania”.

Rozmowa (dialog) wymaga znajomości konwencji związanych np. z jej rozpoczynaniem czy kontynuowaniem oraz "adekwatnych w tym kontekście pytań" 21 , a to obszar, w którym obserwuje się znaczne deficyty u osób z zespołem Aspergera. Dzieci mają trudności z tworzeniem wypowiedzi adekwatnie do odbiorcy, sytuacji, miejsca, celu komunikatu, a więc w zakresie sprawności komunikacyjnej, co wynika ze schematyzmu języka, zaburzonej empatii, jednostronnego typu interakcji społecznych charakterystycznych dla ZA. Komunikację niewerbalną osób z tym rozpoznaniem cechują zaburzenia suprasegmentalne, a więc dotyczące melodii, akcentu rytmu wypowiedzi. Pacjenci stosują nietypową intonację, ich głos może być piskliwy, nienaturalnie nastawiony22. Przejawiają też trudności w wyrażaniu i odbiorze komunikacji opartej o kod pozajęzykowy. Mają kłopot z nawiązywaniem kontaktu wzrokowego, a on jest istotnym elementem rozmowy, sygnałem świadczącym np. o chęci jej zainicjowania, oznaką zainteresowania interlokutorem i tematem konwersacji. Przejawiają trudności w wyrażaniu i odbiorze gestów i mimiki, w związku z tym mogą nie rejestrować pozajęzykowo manifestowanych sygnałów np. zniecierpliwienia, znużenia czy zdenerwowania.

Wymienione deficyty zwłaszcza nieprawidłowości dotyczące sprawności komunikacyjnej, nieprzestrzeganie rytmu komunika-

21 T. Attwood, op. cit., s. 61.

22 D. Graaisma, Rozstrojone umysty. Dzieje chorób i historie chorób, PIW, Warszawa 2009 . 
cyjnego, schematyzm języka, trudności w rozumieniu żartów, uporczywe powracanie do pewnych tematów utrudniają w oczywisty sposób odgrywanie roli kolegi. „Dziwne” brzmienie głosu, stosowanie zbyt wyszukanego, dorosłego, niezrozumiałego dla pozostałych dzieci języka może być przyczyną wyśmiewania, dokuczania ze strony pozostałych uczniów. Badania potwierdzają istnienie korelacji pomiędzy umiejętnościami komunikacyjnymi a akceptacją rówieśników ${ }^{23}$. Również badania prowadzone przez autorkę artykułu dotyczące sytuacji szkolnej dzieci z trudnościami komunikacyjnymi - polskich jąkających się dzieci - wykazały, że większość badanych doświadcza dokuczania ze strony rówieśników w związ$\mathrm{ku} z$ kłopotami w porozumiewaniu ${ }^{24}$.

Dosłowność w odbiorze języka, trudności z rozumieniem metafor, nieprawidłowości dotyczące narracji przejawiające się kłopotami w uchwyceniu zależności przyczynowo-skutkowych, czasowych, przestrzennych czy błędami fleksyjnymi oraz nieprzestrzeganie rytmu komunikacyjnego obowiązującego na lekcji mogą utrudniać osiąganie sukcesów także w roli ucznia. Zdarza się, że dziecko z zespołem Aspergera bezwiednie narusza regulamin szkoły, który zabrania używania słów uznanych za wulgarne, „brzydkie”, niestosowne. Przyczyną złamania wytycznych w tym zakresie jest brak uwzględnienia przez ucznia z ZA kulturowego aspektu używania słów ${ }^{25}$. Do naruszenia szkolnego kodeksu może dojść także świadomie, poprzez użycie "tych" słów w celach manipulacyjnych, po to, aby kontrolować i wpływać na reakcje osób dorosłych. Dlatego

${ }^{23}$ P.A. Hadley, M. Rice, Conversational resposiveness of speech and language impaired preschoollers, "Journal of Speech and Hearing Research" 1991, nr 34, s. 1308-1317; T.M. Gallagher, Language sill and the development of social competence in schoo-age Children. "Language, Speech and Hearing Services in the Schools” 1993, nr 24, s. 199-205.

${ }^{24}$ K. Węsierska, E. Gacka, M. Langevin, M. Węsierska, Sytuacja szkolna dzieci jąkających się w Polsce - wstępne wyniki badań $i$ strategie pomocy, [w:] Zaburzenia ptynności mowy. Teoria i praktyka. T. 1, red. K. Węsierska, Wydawnictwo Komlogo, Katowice 2015, s. 221-235.

${ }^{25}$ M. Korendo, op. cit. 
poznanie i zrozumienie specyfiki zachowań komunikacyjnych dzieci z ZA pomaga rodzicom i nauczycielom w odpowiednim postępowaniu oraz wyznacza pożądane kierunki oddziaływań terapeutycznych.

\section{Pomoc dziecku z ZA}

Dziecko z zespołem Aspergera potrzebuje terapii uwzględniającej nieprawidłowości w obszarze językowym, społecznym i emocjonalnym. Wszystkie te obszary są istotne i wszystkie ze sobą powiązane. $\mathrm{W}$ organizowaniu pomocy wyraźnie należy podkreślić ogromną rolę terapii logopedycznej skoncentrowanej na deficytach językowych i komunikacyjnych, gdyż przy pomocy języka kształtujemy zachowania społeczne i emocjonalne. Język pozwala nam na poznawanie rzeczywistości, jest "śsieżką wiodącą do ludzkich emocji i chceń, a także wyznacznikiem [...] możliwości istnienia człowieka w grupie społecznej"26.

Działania pomocowe dla dzieci z zespołem Aspergera powinny polegać na:

- wczesnym rozpoznaniu problemu i wczesnym objęciu specjalistyczną opieką (psychiatryczną, psychologiczną, logopedyczną, pedagogiczną);

- oferowaniu pomocy zarówno dziecku, jak i rodzinie; rodzice potrzebują fachowej wiedzy oraz wsparcia psychicznego W związku z pojawiającymi się zarzutami o brak kompetencji wychowawczych (otoczenie tłumaczy zachowania dzieci z ZA w kategoriach "zlego wychowania");

- propagowaniu informacji o zaburzeniu wśród nauczycieli (przedszkoli, szkół: podstawowych, gimnazjalnych, licealnych oraz wyższych);

- zapobieganiu izolacji, wykluczaniu społecznemu dzieci z ZA, przeciwdziałaniu wszelkim formom dokuczania, wyśmiewa-

${ }^{26}$ S. Grabias, O ostrość refleksji naukowej..., s. 61. 


\begin{abstract}
nia, znęcania (przeciwdziałaniu bullyingowi), edukowaniu całej społeczności szkolnej w zakresie działań antybullingowych; - promowaniu postaw otwartości, tolerancji i akceptacji dla innych.
\end{abstract}

\title{
Bibliografia
}

Attwood T., Zespól Aspergera, Wydawnictwo Zysk i S-ka, Poznań 2006.

Błaszczyk-Kowalska S., Gacka E., Rozwój komunikacji językowej u dzieci z zespołem Aspergera, „Problemy opiekuńczo-wychowawcze” 2015, nr 10.

Błeszyński J.J., Autyzm a niepetnosprawność intelektualna i opóźnienie w rozwoju. Skala oceny zachowań autystycznych, Harmonia Universlis, Gdańsk 2016.

Bryńska A., Deficyty językowe w zespole Aspergera jako możliwy wyraz dysfunkcji prawopótkulowej. „Psychiatria i psychologia kliniczna” 2010, 10(4).

Cieszyńska-Rożek J., Metoda Krakowska wobec zaburzeń rozwoju dzieci. Z perspektywy fenomenologii, neurobiologii i językoznawstwa, Omega Stage Systems, Kraków 2013.

Diagnostic and statistical manual of mental disorders, 4 th Ed, rev. (DSM-IV), American Psychiatric Assotiation, Washington 1994.

Gajda S., Jak się porozumiewamy?, [w:] Logopedia. Pytania i odpowiedzi. Podręcznik akademicki. Interdyscyplinarne podstawy logopedii. Tom I, red. T. Gałkowski, G. Jastrzębowska, Wydawnictwo Uniwersytetu Opolskiego, Opole 2003.

Gajda S., Wprowadzenie, [w:] Logopedia. Pytania i odpowiedzi. Podręcznik akademicki. Interdyscyplinarne podstawy logopedii. Tom I, red. T. Gałkowski, G. Jastrzębowska, Wydawnictwo Uniwersytetu Opolskiego, Opole 2003.

Gallagher T.M., Language sill and the development of social competence in schoo-age Children. „Language, Speech and Hearing Services in the Schools” 1993, nr 24.

Gillberg C., Gillberg C., Asperger syndrome - Some epidemiological considerations: A reaserch note, "Journal of Child Psychology and Psychiatry", vol. 30.

Graaisma D., Rozstrojone umysty. Dzieje chorób i historie chorób, PIW, Warszawa 2009.

Grabias S., Interakcja językowa $i$ jej uwarunkowania. Perspektywa lingwistyczna, [w:] Bariery i pomosty w komunikacji językowej Polaków, red. J. Bartmiński, U. Majer-Baranowska, Wydawnictwo UMCS, Lublin 2005.

Grabias S., O ostrość refleksji naukowej. Przedmiot logopedii i procedury logopedycznego postępowania, [w:] Logopedia. Wybrane aspekty historii, teorii i praktyki, red. S. Milewski, K. Kaczorowska-Bray, Harmonia Universalis, Gdańsk 2012.

Grabias S., Postępowanie logopedyczne. Diagnoza, programowanie terapii, terapia, "Logopedia" 2008, t. 28.

Grice H.P., Logic and conversation, [w:] Syntax and semantics, red. P. Cole, J.L. Morgan, V/3, Academic Press, New York 1975. 
Grice H.P, Logika i konwersacja, „Przegląd Humanistyczny” 1977, nr 6.

Hadley P.A., Rice M., Conversational resposiveness of speech and language impaired preschoollers. "Journal of Speech and Hearing Research” 1991, nr 34.

Kaczmarek B., Misterne gry w komunikacje, Wydawnictwo UMCS, Lublin 2010.

Klasyfikacja zaburzeń psychicznych i zaburzeń zachowania w ICD-10. Badawcze kryteria diagnostyczne, red. S. Pużyński, J. Wciórka, Uniwersyteckie Wydawnictwo Medyczne „Vesalius", Instytut Psychiatrii i Neurologii, Warszawa 2007.

Korendo M., Jezykowa interpretacja świata w wypowiedziach osób z zespołem Aspergera, Omega Stage Systems, Kraków 2013.

Maciarz A., Biedasiewicz M., Dziecko autystyczne z zespotem Aspergera. Studium przypadku, Oficyna Wydawnicza „Impuls”, Kraków 2000.

Morrison J., DSM-V® bez tajemnic. Praktyczny przewodnik dla klinicystów, Wydawnictwo UJ, Kraków 2016.

Panasiuk J., Kaczyńska-Haładyj M.M., Postępowanie logopedyczne w przypadku osób dorostych z zespotem Aspergera, [w:] Logopedia. Standardy postępowania logopedycznego. Podręcznik akademicki, red. S. Grabias, J. Panasiuk, T. Woźniak, Wydawnictwo UMCS, Lublin 2015.

Szacka B., Wprowadzenie do socjologii, Oficyna naukowa, Warszawa 2008.

Urbaniak J., „Mali profesorowie czy inteligentni autyści. Wczesna diagnoza dziecka z zespotem Aspergera, [w:] Wczesna interwencja $i$ wspomaganie rozwoju matego dziec$k a$, red. B. Cytowska, B. Winczura, Oficyna Wydawnicza „Impuls”, Kraków 2006.

Węsierska K., Gacka E., Langevin M., Węsierska M., Sytuacja szkolna dzieci jąkających się w Polsce - wstępne wyniki badań i strategie pomocy, [w:] Zaburzenia ptynności mowy. Teoria i praktyka. T. 1, red. K. Węsierska, Wydawnictwo Komlogo, Katowice 2015.

Winczura B., Autyzm, autyzm atypowy a schizofrenia wczesnodziecięca, [w:] Dzieci z zaburzeniami taczonymi. Trudne ścieżki rozwoju, red. B. Winczura, Oficyna Wydawnicza „Impuls”, Warszawa 2012. 